\title{
A new subspecies of Carabus (Imaibius) wittmerorum Hein- ertz, 1978 from Mahabanr Mountains, Khyber province, Swabi district, Pakistan (Coleoptera Carabidae)
}

\author{
André Schneider ${ }^{*}$ \& Ivan Rapuzzi ${ }^{2}$ \\ 1Pelzmühlenstraße 11, 09117 Chemnitz, Germany; email: andre.schneider@hs-mittweida.de \\ ${ }^{2}$ Via Cialla n. 47, 33040 Prepotto (UD), Italy; email: info@ronchidicialla.it \\ *Corresponding author
}

\begin{abstract}
The description of a new subspecies of Carabus (Imaibius) wittmerorum Heinertz, 1978 (Coleoptera Carabidae) from Bir Gali (District Swabi, Province Khyber, Pakistan) is given.

KEY WORDS Coleoptera; Carabidae; Carabus; Imaibius; new subspecies; Pakistan.
\end{abstract}

Received 08.06.2021; accepted 18.07.2021; published online 04.08.2021

\section{INTRODUCTION}

The Carabus Linnaeus, 1758 species of the subgenus Imaibius Bates, 1889 (Coleoptera Carabidae) are found in a geographical area extending from the Pakistan-Afghanistan border in the west and north to the mountains in the provinces of Kashmir and Himachal Pradeh in the east. In recent decades, a number of new species and subspecies have been described thanks to the exploration of new or less known areas, especially the provinces of Khyber Pakhtunkhwa, Gilgit-Baltistan, Punjab and Asad Jammu and Kashmir (Heinertz 1977; Ledoux, 1977; Heinertz, 1978a; Heinertz 1978b; Letellier, 1979; Heinz, 1983; Heinz, 1993; Deuve, 1981; Deuve, 1982; Gottwald, 1992; Deuve \& Kaláb, 2000; Kleinfeld \& Reuter, 2007; Deuve, 2007; Kleinfeld, 2009). Three further species were discovered in Nepal (Mandl, 1974; Lassalle, 1985; Deuve \& Schmidt, 2007).

In the summer of 2020, an area in the province of Khyber Pakhtunkhwa was surveyed that is a possible habitat for Imaibius, but no information was available in the literature so far. The study area in the vicinity of Bir Gali (Beer Gali), is located in the Mahaban Medows, at the intersection of four districts - Haripur, Torghar, Buner and Swabi. The mountain ranges of the area, which are between 1700-2200 m, have predominantly pinewoods. The Mahaban Medows are located about $60 \mathrm{~km}$ southeast of the town of Mingora, in the vicinity of which the two species Carabus (Imaibius) wittmerorum Heinertz, 1978, and Carabus (Imaibius) grandharae Heinertz, 1978, were once found and described.

A small series of Imaibius could be caught, the specimens of which can be distinguished from Carabus (Imaibius) wittmerorum Heinertz, 1978, occurring in the Swat Valley, by their elytra structure as well as the steel-blue reflections of the elytra and the posterior corners of the pronotum. We are describing them as new subspecies in the following lines.

\section{RESULTS}

Ordo COLEOPTERA Linnaeus, 1758 
Subordo ADEPHAGA Schellenberg, 1806

Familia CARABIDAE Latreille, 1802

Subfamilia CARABINAE Latreille, 1802

Genus Carabus Linnaeus, 1758

Subgenus Imaibius Bates, 1889

Carabus (Imaibius) wittmerorum vojtechi $\mathrm{n}$. ssp. https://zoobank.org:act:69058697-0EFE-4E1096C9-CD80E39B955A

Material eXamined. Holotype male, Pakistan, Province Khyber, District Swabi, Bir Gali env., 1900 m, 03.VI.2020, Ikram Ullah legit. The holotype is temporarily housed at the author's collection (André Schneider, Germany) waiting to be definitively deposited in a public Institution. Paratypes: 5 females and 5 males, same data as Holotype. The paratypes are deposited in the author's collections in Italy and Germany.

Description of holotype male. Length, including mandibles, $30 \mathrm{~mm}$ (Fig. 1), maximum width of elytra $12.5 \mathrm{~mm}$. Colour black quite mat, with a faint steel-blue tinge between the secondary and tertiary ribs at the base of the elytra, the margins of the elytra and pronotum. Head, legs, antennae and palps black. Head elongate, quite narrow, neck of normal shape, eyes moderately prominent, tooth of mentum triangular and rounded towards the tip (Fig. 4), upper side very finely punctate. Apical segment of palpi slightly dilatated; penultimate segment of labial palpi multisetose. Second segment of antennae long about half than the third. Sides of pronotum strongly cordate, hearth-shape, broadly set throughout and strongly curved upwards, about 1.6 times as broad as long; hind angles forming triangular lobes, slightly rounded at the end, reaching slightly behind the base, also slightly curved outwards; upper side of pronotum flatly curved, rather densely and moderately coarsely punctate on all margins, median furrow of pronotum visible. Elytra oval but massive, strongly convex, sloping sharply towards the end, the widest part slightly behind the middle; elytral sculpture of slightly heterodyname type, consisting of 15 moderately raised intervals: primary intervals larger and more prominent, interrupted in more or less long and convex segments; secondary smaller, forming ribbed lines or into rows of tubercles; tertiary intervals dissolved into a range of grains. Legs of normal length; male protarsi with 3 dilated and fully soled segments. Male aedeagus (Fig. 5) typical of the species but smaller and slender, apex smaller and lesser bent upwards.

VARIABILITY. Very limited variability. It concerns the size that ranges from $28 \mathrm{~mm}$ to $30 \mathrm{~mm}$ for the males and $33 \mathrm{~mm}$ to $36 \mathrm{~mm}$ for the females. The colour is very constant, in some specimens are more pronounced the blue shimmer of the elytra and hind-angles of pronotum.

Etymology. The new subspecies is warmly dedicated to the unforgotten Vojtěch Merta (19972019).

Distribution. Carabus (Imaibius) wittmerorum Heinertz, 1978 is distributed in a small area of the Swat Valley of less than $100 \mathrm{~km}^{2}$ (Heinz, 1983; Heinz, 1979). The area is bounded by the following locations: Miandam, Jabba and Shangla (Heinz, 1983; Deuve, 1984).

The new subspecies appears to be isolated in the Mahaban Medows, a 1700-2200 m high mountain range, on the left side of the Indus Valley and on the south side of the Barandu River.

Comparative notes. The new subspecies is closely related with nominate form of $C$. (Imaibius) wittmerorum Heinertz (1978), but easy to be distinguished by the following characteristics: elytra sculpture, clearly broader pronotum, clearly less coloured upper side of the elytra and lateral margins of the pronotum, male aedeagus smaller and slender, the specimens appear broader in build. Distinguishable from C. (Imaibius) caschmirensis Redtenbacher, 1842, by the following characteristics: less convex intervals of elytra; margins of pronotum and elytra colored; different shape of aedeagus. Furthermore, the new subspecies can be clearly distinguished from $C$. (Imaibius) pachtoun marysae Letellier, 1979, from the Swat Valley by the following characteristics (Letellier, 1979; Heinz, 1983): wider primary and secondary intervals of elytra, wider pronotum, shorter and broader shape, tooth of mentum not bluntly triangular and expanded perpendicular to the body into a pedunculate plate. Finally, the new subspecies can be clearly distinguished from $C$. (Imaibius) grandharae Heinertz, 1978 (including subspecies pseudograndharae Deuve, 1995) by the following characteristics (Heinertz, 1978; Heinz, 1983; Deuve, 1995): primary intervals less raised and interrupted in the specimens known so 


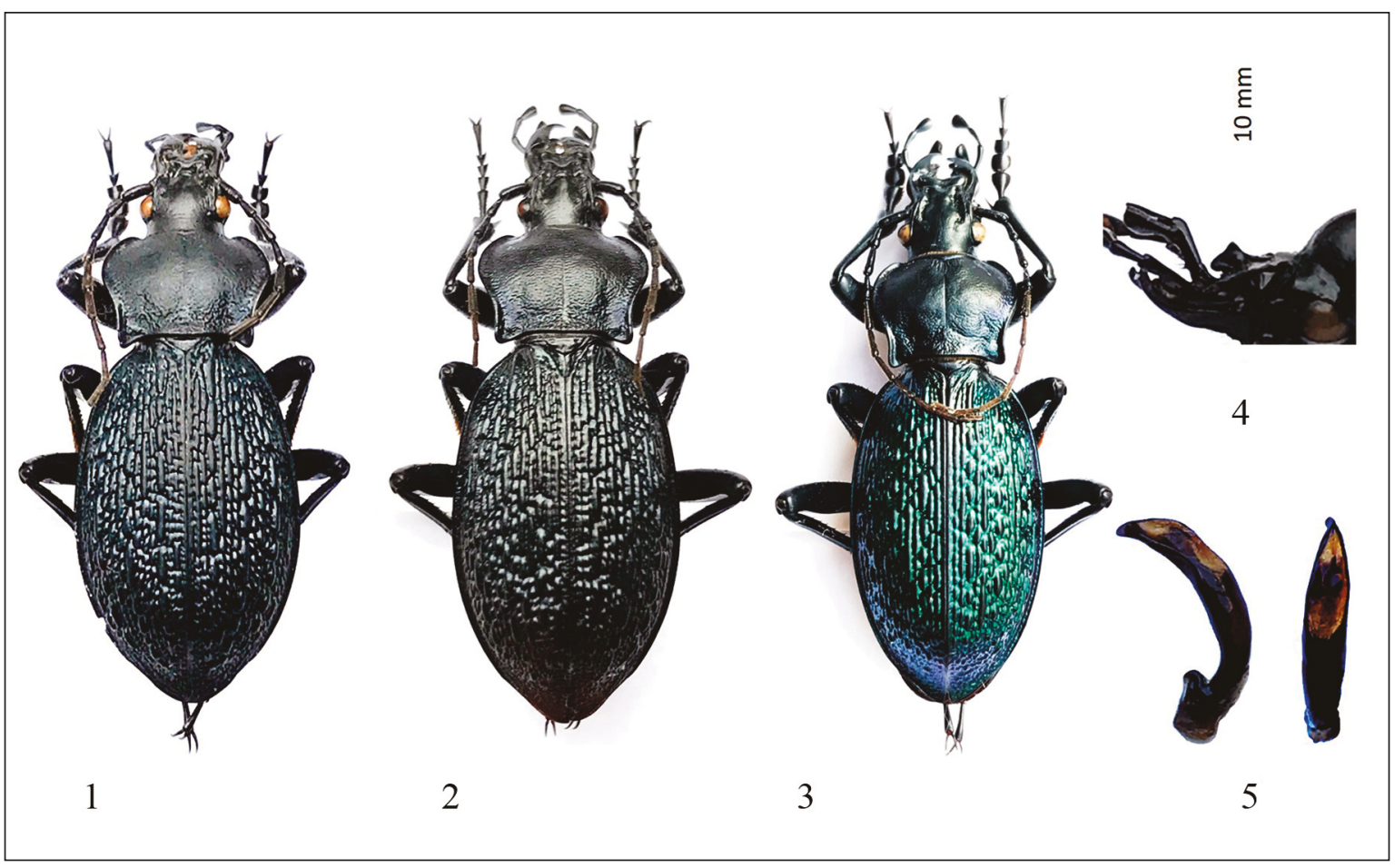

Figures 1-5. Carabus (Imaibius) wittmerorum vojtechi n. ssp. holotype (Fig. 1); Carabus (Imaibius) wittmerorum vojtechi n. ssp. paratype female (Fig. 2); Carabus (Imaibius) wittmerorum wittmerorum Heinertz, 1978 (Fig. 3); tooth of mentum (Fig. 4); aedeagus in dorsal and lateral view from holotype (Fig. 5).

far; secondary and tertiary intervals more irregular and not forming ridges; wider pronotum; aedeagus broader and clearly blunter ending; shape larger and broader.

\section{ACKNOWLEDGEMENTS}

We are grateful to our colleague Ikram Ullah for planning and carrying out the research trip in Pakistan, despite the difficult conditions during a lockdown triggered by the Covid 19 pandemic. Sincere thanks go to Ms Senta Kühnhardt for her support in organizing the project.

\section{REFERENCES}

Brezina B., 2008. The Check-list of the Genus Carabus (Coleoptera, Carabidae).

Deuve T., 2019. Classification du genre Carabus L., 1758. Liste Blumenthal 2018-2019 (Coleoptera, Carabidae). Coléopterères, 25: 33-102.

Deuve T., 2004. Illustrated Catalogue of the Genus
Carabus of the World (Coleoptera, Carabidae). Edit. PENSOFT. Sofia-Moscow.

Deuve T., 1984. Liste descriptive des Carabes du sousgenre Imaibius Bates. Miscellanea Entomologica, 50: 109-129.

Deuve T., 1984. Remarques sur quelques Carabes du sous-genre Imaibius Bates (Coleoptera, Carabidae), Entomologica Basiliensia, 9: 67-74.

Deuve T. \& Letellier P., 1980. Description d'un Imaibius nouveau du Pakistan (Col., Carabidae). - Nouv. Rev. Entomol., 10: 11-13.

Deuve, T. \& Schmidt, J. 2007. Description d'un nouvel Imaibius du Népal. Revue Française d'Entomologie (N. S.), 29 : 11-14.

Heinertz, R., 1977. Eine neue Carabus-Art der Subgattung Imaibius Bates aus Pakistan (Col., Carabidae). Entomologica Basiliensia, 2: 423-426.

Heinertz, R., 1978. Zwei neue Carabus (Imaibius)-Arten aus Pakistan (Col., Carabidae). Entomologica Basiliensia, 3: 619-622.

Heinz W., 1993. Neue Carabus-Formen aus dem nordwestlichen Pir-Panjal (Col. Carabidae). Entomologica Basiliensia, 16: 13-36.

Heinz W., 1983. Synopsis der Carabus-Arten Pakistans und der westlichen indischen Teile des Himalajas (Coleoptera, Carabidae). Entomologica Basiliensia, 8: 88-107. 
Heinz W. \& Staven K., 1998. Neue Erkenntnisse an Carabus (Imaibius)-Arten aus dem pakistanischen Himalaya (Coleoptera: Carabidae). Entomologische Zeitschrift, 108: 261-304.

Kleinfeld F. \& Schütze H., 1997. Systematische Liste der Gattung Carabus. Fürth-Gleichen.

Ledoux G., 1975. Une nouvelle espèce d'Imaibius d’Afghanistan (Col. Carabidae). L`Entomologiste, 31: 129-131.
Letellier P., 1979. Description d'une nouvelle sous-espèce du Carabus (Imaibius) caschmirensis Redt. (Coleoptera: Carabidae). Entomologica Basiliensia, 4: 165-167.

Mandl K., 1985. Framenta Carabologica 7. Wiederherstellung und Revision des Subgenus Tropidocarabus Kraatz des Genus Carabus L. und Bemerkungen zu einigen Taxa des Subgenus Imaibius Bates. Entomologica Basiliensia, 10: 85-122. 